\title{
On the Development of Scientific Terminology in African Languages: The Terminographer's Dilemma in a New Dispensation*
}

\author{
Louis Jacobus Louwrens, Department of African Languages, \\ University of South Africa, Pretoria, South Africa
}

\begin{abstract}
There currently exists a noticeable tension in South Africa between the political aim of one homogeneous South African nation on the one hand and the autonomy each language deserves in practice according to the constitution on the other. The real development of individual languages and the purposeful cultivation of language pride necessarily accentuate races and ethnical differences, which are contrary to the ideal of nation-building. Consequently, languages are subtly denied acknowledged constitutional rights in practice, which will impact negatively on the development of especially the African languages into technical and academic languages in their own right. The question thus arises whether it is sensible for the terminographer to develop scientific and technical terms for the African languages, while everything at this stage indicates that these terms will hardly, if ever, be used by subject specialists.
\end{abstract}

Keywords: TERMINOLOGY, AFRICAN LANGUAGES, LANGUAGE ATTITUDES, MEDIUM OF INSTRUCTION, LANGUAGE-TEACHING, LINGUISTIC AWARENESS, LANGUAGE PLANNING, LANGUAGE POLICY, MULTILINGUALISM, NATION-BUILDING, CONSTITUTIONAL RIGHTS, HARMONIZATION, STANDARD LANGUAGE, STANDARD SOTHO, STANDARD NGUNI, LANGUAGE BOARDS, LANGUAGE ACADEMIES, ETHNICITY, MONOLINGUAL SCHOOLS, RADIO SERVICES

Opsomming: Oor die ontwikkeling van wetenskaplike terminologie in Afrikatale: die terminograaf se dilemma onder ' $n$ nuwe bedeling. Daar bestaan tans ' $n$ merkbare spanning in Suid-Afrika tussen die politieke strewe na een homogene en ongedifferensieerde nasie enersyds, en die outonomie waarop elke taal konstitusioneel in die praktyk geregtig is andersyds. Die daadwerklike uitbouing van individuele tale en die doelgerigte kweek van ' $n$ taaltrots aksentueer noodwendig rasse en etriese verskille, wat direk in stryd is met die ideaal van nasiebou. Gevolglik word tale in die praktyk op subtiele wyse vele konstitusioneel erkende regte ontsé wat veral die Afrikatale se ontwikkeling tot volwaardige tegniese en akademiese tale nadelig beïnvloed. Die vraag ontstaan dus of dit in so ' $n$ klimaat vir die terminograaf sin maak om wetenskaplike en tegniese terme vir die Afrikatale te ontwikkel, terwyl alles in hierdie stadium daarop dui dat sodanige terme selde, indien ooit, deur vakspesialiste gebruik gaan word.

This paper was presented at the First Intemational Conference of the African Association for Lexicography, held at the Rand Afrikaans University, Johannesburg, 1-2 July 1996. 
Sleutelwoorde: TERMINOLOGIE, AFRIKATALE, TAALHOUDINGS, ONDERRIGMEDIUM, TAALONDERRIG, TAALBEWUSTHEID, TAALBEPLANNING, TAALBELEID, VEELTALIGHEID, NASIEBOU, KONSTITUSIONELE REGTE, HARMONISERING, STANDAARDTAAL, STANDAARDSOTHO, STANDAARDNGUNI, TAALRADE, TAALAKADEMIES, ETNISITEIT, ENKELMEDIUMSKOLE, RADIODIENSTE

In the "New South Africa", the terminographer involved in the development of scientific terminology in African languages is faced with one major uncertainty brought about mainly by two factors, namely (a) existing attitudes regarding the suitability of the indigenous languages for the purposes of scholarly discourse, and (b) the way in which the autonomy of these languages is affected by the ideal of nation-building. As for the first point, two views can be distinguished: on the one hand, there are those who feel that the teaching of African languages through a medium other than the vernacular itself is totally inexcusable; on the other, there are scholars who maintain that the indigenous languages are, at least for the present, not adequately equipped to be used as media of instruction on a tertiary level. Currently the latter view predominates, which explains the existing practice whereby African languages are taught mainly, for example at tertiary institutions, through the medium of either English or Afrikaans. This poses a serious problem for the terminographer, which leads to the question whether it is worth the time and effort to embark on ambitious projects for the development of terminology if there is no proof that these languages will indeed in future reach a point where they will become accepted as worthy means of scholarly discourse. These two issues are addressed below and disquieting developments are identified which clearly reveal how South Africa's indigenous languages are in practice denied the autonomy they constitutionally deserve - a situation which calls for a reassessment of the terminographer's position in a future dispensation.

Any effort to expand the scientific terminology of an African language rests on the tacit assumption that, in future, the language will become a language of learning. If this is not the case, what sense does it make to spend manpower, time and money on term development if tuition at tertiary level is certainly going to be conducted mainly through a medium other than the language concerned?

Although the vision that the African languages can be developed into appreciable languages of science and technology is not far-fetched, it is not always met with the same degree of enthusiasm by scholars and university teachers, and here both mother-tongue and non-mother-tongue speakers are included. It will, therefore, be unwise for the terminographer to occupy him- or herself with the development of terminology without assessing in advance how the outcome of such an endeavour will be received.

The following remark by Nkondo (1987: 72) represents the viewpoint of those who totally reject the idea of teaching African languages through a medium other than the vernacular itself: 
For the native speaker no didactic principle would suggest anything other than the language itself for the medium of study. This is a very thorny issue, as we know, in spite of its obviousness. Arguments of internationalization or reaching a wider readership are indefensible.

Supporters of this view are often adamant that the status quo should be changed immediately, notwithstanding some almost insurmountable problems which would face the university teacher should this happen haphazardly. Furthermore, they claim that the poor performance of mother-tongue speakers at university level can mainly be attributed to students' poor proficiency in English due to ineffective schooling at pre-university level. With regard to mother-tongue instruction, the problem is aggravated by the fact that the teaching of African languages at secondary level is conducted through the medium of the vernacular, whereas at tertiary level the student is expected to switch to a foreign medium of instruction. Consequently, the questionable view is held that mother-tongue instruction through the medium of the mother tongue will lead to a dramatic increase in the pass rate of students in first language courses.

On the contrary, there are scholars who are strongly opposed to the view that African languages should be taught through the medium of the vernacular. One of the major arguments raised by this group is that the lack of terminology makes it impossible - at least for the moment - to achieve the standard of scientific reasoning which is expected at university level. One would then assume that, given the availability of an elegant and sophisticated terminology, this objection against the use of the vernaculars as media of instruction will fall away. That does not seem to be the case, however, since a second prominent argument raised by supporters of this view is that English is the international language through which scientific knowledge is accessed. It will hence serve very little purpose to present theses, dissertations, conference papers and scientific articles in an African language, because such contributions will deny international researchers as well as many fellow South Africans the privilege of sharing in newly acquired knowledge. Scholars and researchers therefore steer away form the vernaculars when it comes to academic work. So, for example, statistics reveal that during the period 1985-1995 only one article written in an African language was published in the South African Journal of African Languages despite the fact that the editorial policy of this journal makes provision for contributions in languages other than English. Even Afrikaansspeaking academics prefer to publish in English in order to reach a wider local and international readership. These observations reveal deeply rooted prejudices against the African languages, which will undoubtedly hamper their future development as languages of learning.

Against this background, the question arises whether it will be worthwhile to develop elaborate sets of scientific terms for African languages, given the very clear signals that a substantial number of scholars will probably 
never, or only rarely, use them. This question can be approached in one of two possible ways - the one rather negative; the other more positive. Viewed negatively, the terminographer could adopt the view that since there are no guarantees that the existing prejudices towards the indigenous languages will disappear, terminographic work undertaken in advance would be premature. Is there any assurance that even the most comprehensive and scientifically sophisticated set of terms will, in the long run, change the minds of those who are currently in favour of English? Viewed more positively, it could be argued that the terminographer should not focus on the here and the now, but on the future. Attitudes may change for a variety of reasons, such as, for instance, the launching of vibrant language-awareness programmes as suggested in many of the subcommittee reports of the Language Plan Task Group discussed at a national conference held on 29 June 1996. It could therefore be argued that when a new linguistic awareness awakens, a properly developed terminology needs to be in place to serve a variety of language users at different levels.

The vision of African languages becoming accepted media of instruction at tertiary level is not so unrealistic, particularly if cognisance is taken of what happened elsewhere in the world. Discussing the advent of German as a literary language during the eighteenth century, Cluver (1987: 27) observes that a language's surge forward can be amazingly swift, provided that nationalism has, due to whatever contributing factors, reached that critical point which inspires a people to reassess its cultural heritage.

The question is, however, whether the present climate in South Africa is indeed conducive to the awakening of such a renewed linguistic nationalism. This does not seem to be the case, due to a disturbing conflict between the politically inspired vision of one homogeneous South African nation on the one hand, and the ideal of promoting multilingualism on the other. The active promotion of multilingualism, that is the promotion of the different languages as unique entities spoken by different racial and ethnic groups, directly opposes the ideal of establishing maximum cohesion and unity among the peoples of this country. The quest for a single undifferentiated "rainbow nation" requires, of necessity, the systematic eradication of everything that might distinguish one group from another. Linguistic identity, therefore, becomes a problem in as far as it enshrines racial and ethnic diversity. Despite what is written in the Constitution, the careful observer becomes aware of a number of subtly disguised initiatives which are all intended to obstruct whatever might inspire the awakening of a renewed linguistic awareness. The following can be cited as examples of endeavours aimed at maximising national unity:

(1) At a workshop of the Language Plan Task Group's Subcommittee on the Development of South African Languages that was held at the University of South Africa on 28 March 1996, it became clear that this subcommittee has been assigned the task, inter alia, of advising the Ministry of 
Arts, Culture, Science and Technology on the feasibility of the harmonization of the African languages. In its most extreme sense, harmonization amounts to the unification of languages which belong to the same language group into one so-called "standard language" of unpredictable composition. In practice, this scenario would entail the harmonization of Northern Sotho, Southern Sotho and Tswana into so-called "Standard Sotho", and the harmonization of Xhosa, Swati, Zulu and Ndebele into so-called "Standard Nguni". Fortunately, this proposal was met with severe opposition at the national conference of the Language Plan Task Group that was held on 29 June 1996, and the matter was postponed for the time being, pending further research. The question that remains unanswered, however, is why, in the first place, the Ministry regarded it necessary to put this point on the agenda? Given the agreements reached during constitutional negotiations regarding the autonomy of the country's eleven languages, it becomes difficult - if not impossible - to reconcile the concept of harmonization with the undertaking given in the Constitution, namely:

Recognising the historically diminished use and status of the indigenous languages of our people, the state must take practical and positive measures to elevate that status and advance the use of these languages.

A second controversial point discussed at some length at the said subcommittee workshop relates to the status of what has been labelled "Apartheid Language Boards". On the one hand, there were those who felt strongly that Language Boards are nothing but relics of the old apartheid system in which they were used as political tools to divide people who actually belonged together. Supporters of this view therefore proposed that these Boards be replaced by Language Academies of a non-ethnic nature by bundling together languages which belong to the same language group such as, for example, Northern Sotho, Southern Sotho and Tswana under one and the same Language Academy. Supporters of this view furthermore voiced the idea that in future the emphasis should be on the similarity between languages, and not on the differences which exist between them. On the other hand, there were those who were adamant that each language deserves its own academy, since it is constitutionally entitled to it - a view that fortunately enjoyed the support of the majority of delegates at the national conference of the Language Plan Task Group referred to above. Some supporters of the latter view did not hesitate to point out that the old Language Boards played a major role in the upliftment of South African languages to the extent that they are much further developed today than most of the languages in the rest of Africa. But the mere fact that influential linguists, 
language practitioners and government officials are divided on such an obvious point, namely whether languages should in practice be granted the privileges and autonomy which they are constitutionally entitled to, is symptomatic of a climate that will suffocate rather than stimulate the revival of a renewed linguistic awareness.

(3) Thirdly, the severe opposition with which the principle of monolingual schools was met during recent constitutional negotiations can be recalled. This principle has not been enshrined in the Constitution, since it is viewed as being in direct conflict with the concept of nation-building. The ideal of one homogeneous nation cannot be attained if children are allowed to be educated in separate schools and in separate languages. Multilingual schools, on the contrary, are very useful and effective instruments in the equalising process, since they will, in the long run, gradually erode linguistic awareness which, in its turn, will ultimately lead to the demolition of linguistic boundaries between groups.

(4) The fourth example of this equalising strategy pertains to the changing of names of radio services. The principle has been adopted that no radio station will in future use in its name the name of the language in which it communicates with its listeners. Names like Radio Tsonga, Radio Zulu, Afrikaans Stereo and the like are being replaced by more neutral labels, since the identification of a particular broadcasting service with a specific language once again underscores the uniqueness of that language and the people who speak it. Such a situation cannot be tolerated since it undermines the vision of one homogeneous and undifferentiated nation.

The picture sketched above leads to a number of questions, for instance: How can the awakening of a renewed linguistic nationalism be envisaged if not only politicians, but also a number of very influential linguists, support efforts which are intended to destroy the identity and autonomy of the languages involved? How is the Language Plan Task Group's view that multilingualism is not a problem but an asset, to be reconciled with initiatives such as those mentioned above, which are obviously aimed at suppressing the emergence of a renewed linguistic awareness? Given these developments it becomes very difficult to accept that the African languages will ever reach a point where they become fully fledged languages of science and technology.

In the light of these observations, the terminographer will have to asses carefully the relevance of his or her present activities in terms of the possible future status of the African languages in this country. As one prominent terminographer puts it, the question that needs to be answered is analogous to one asked by a railway company intending to build a new railway line across a deserted country. Should it proceed with the building project in the hope that a new town will emerge at the end of the line after its completion, or should it rather wait for the town to develop first before it starts building the line? 
Terminographic work can only be of value if language users, and particularly subject specialists, sincerely appreciate and fully utilise the terminographer's output. No matter how well-trained and resourceful terminographers are, and no matter how elegant and sophisticated the terms which they create might appear to be, terminographic work in the African languages stands in danger of becoming a wasteful endeavour if the language issue is politicised to the extent that linguistic diversity is subjected to the ideal of nation-building. Unless each and every language is in practice granted all the privileges it is constitutionally entitled to, and unless honest efforts are initiated that will create a climate which will stimulate the growth of a renewed language pride among speakers of all the different languages, it is doubtful whether the indigenous languages will ever develop much further than their present position.

\section{References}

Cluver, A. de V. 1987. A Sociolinguistic Approach to the Study of Technical Languages. Logos 7(2): 13-30.

Nkondo, C.P.N. 1987. Problems of Terminology in African Languages with Special Reference to Xitsonga. Logos 7(2); 69-78. 